\title{
Comunicação oral de laringectomizados com prótese traqueoesofágica: análise comparativa pré e pós-treino ${ }^{* * * * * *}$
}

\author{
Oral communication of laryngectomized patients with \\ tracheoesophageal prosthesis: pre and post-treatment \\ comparative analysis
}

\author{
Iára Bittante de Oliveira* (ibittante@uol.com.br) \\ Claudiney Candido Costa** \\ José Francisco Salles Chagas*** \\ Elaine Cristina Gonçalves Rochetti**** \\ Luciane Otranto de Oliveira*****
}

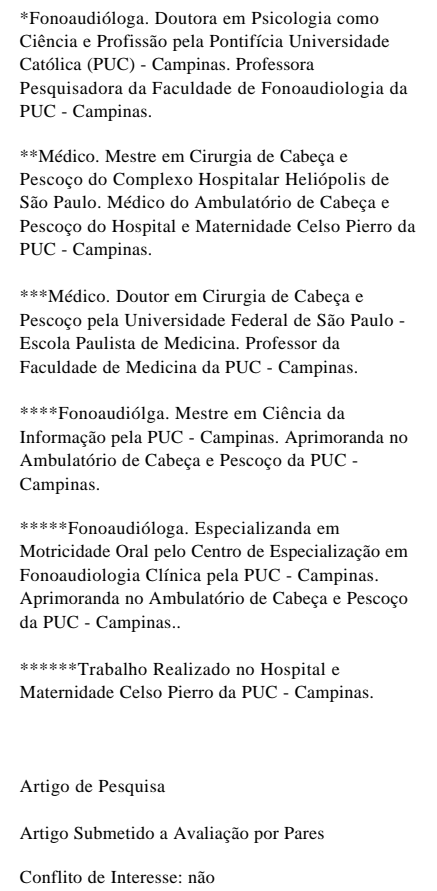

Conflito de Interesse: não

Recebido em 31.01.2003.

Revisado em 3.04.2003; 15.09.2004; 4.02.2005;

22.04.2005.

Aceito para Publicação em 5.07.2005.

\begin{abstract}
Background: speech and voice training for laryngectomized patients with tracheoesophageal prosthesis. Aim: to compare the quality of oral communication of a group of laryngectomized patients with tracheoesophageal prostheses, pre and post speech and voice training. Method: voice and speech samples of 17 laryngectomized patients were analyzed before and after receiving speech and voice training. The voice and speech samples were mixed and presented to speech-language pathologists for assessment. Results: statistically significant (Binomial Test) improvement was observed. Conclusion: it can be concluded that the proposed training improved the speech patterns, including melody and singing.

Key Words: Speech Intelligibility; Laryngectomy; Head and Neck Neoplasms.
\end{abstract}

\section{Resumo}

Tema: treinamento fonoaudiológico para pacientes laringectomizados totais com prótese traqueoesofágica. Objetivo: comparar a qualidade da comunicação oral de pacientes laringectomizados, com prótese traqueoesofágica antes e depois de treinamento fonoaudiológico. Método: foram analisadas amostras de voz e fala de 17 pacientes laringectomizados, antes e depois de treinamento de voz e fala. As amostras pré e póstreino foram misturadas ao acaso e apresentadas a fonoaudiólogos para avaliação. Resultados: observada melhora significativa (Teste da Binomial) no conjunto dos aspectos avaliados. Conclusão: pode-se considerar que o treino proposto melhorou os padrões de fala inclusive a melodia e do canto.

Palavras-Chave: Inteligibidade de Fala; Laringectomia; Neoplasias de Cabeça e Pescoço. pré e pós-treino). Pró-Fono Revista de Atualização Científica, Barueri (SP), v. 17, n. 2, p. 165-174, maio-ago. 2005. 


\section{Introduction}

Considering that the human being is innately vocal and has presented since its birth intentional vocal manifestation, it seems unconceivable that after a long time living with the ability to communicate through the voice, a person may have to deal with the fact that he/she is no longer able to use it initiating a silent life and, frequently, socially isolated.

It is known that laryngealcancer, when requires the complete organ removal, jeopardises the patient's quality of life, since the phonation, breathing and swallowing functions are severely damaged (Blom, Singer \& Hamaker, 1986). The absence of oral communication, as a consequence of this condition, may be considered as the main sequela. It is also important to indicate that in Brazil there is an impressive number of illiterate adults and, in this particular situation, it would not be possible to replace oral communication by the written one.

The total Laryngectomy results in a deep impact on the patient's life, who suffers a rupture in oral communication, jeopardizing his social and familiar relationships (Costa et al, 2001). Speech rehabilitation aims to establish the patient's phonation, which may lead to his social and body reintegration, after a "physical mutilation and voice absence". (Greco et al, 2003).

Since the rising of the surgical procedure of total Laryngectomy for laryngeal cancer, by Billroth, in 1873, reported by Nascimento (1999), clinicians have been challenged to devise effective means of oral communication that may replace laryngeal production.

Esophageal voice as a replacement of the laryngeal voice had its start even before Billroth's in 1851 . Reinaud related a study case presenting a man who had an effective esophageal voice, developed from a larynx stenosis, apud Behlau et al (1988). Esophageal voice is one of the most used laryngeal means of communication (Greco et al., 2003).

Blom et al. (1986), however, point out that only $45 \%$ of patients fail in esophageal voice development.

The use of standard esophageal voice has the advantage of avoiding additional surgeries and use of voice aided by prostheses but may be associated with inadequate vocal intensity in noisy backgrounds (Choy et al., 2001).

Jorge et al (2004) studied two total laryngectomee patients, one with esophageal phonation and the other using a tracheoesophageal prosthesis, and compared them with a normal subject. The authors found that patients using tracheoesophageal prostheses demonstrated similar vocal intensities, fundamental frequencies and maximum phonation times as their normal subject.

Finizia et al (1998) claim that patients who use Tracheoesophageal Prosthesis demonstrate a feeling of plenitude and satisfaction after a successful practice in order to obtain a socially acceptable voice. In addition, the authors concluded that these findings should be considered during the selection of treatment options for patients with laryngeal cancer.

There are many attempts to replace laryngeal voice (Blom, Singer \& Hamaker, 1986; Van As et al, 1998). But the development of TEP is the "greatest technical advance for voice restoration of laryngectomized patient" (Labruna \& Huo, 1995).

This study aimed to evaluate oral communication pre and post-speech training in patients who received In- Health (Blom - Singer) tracheoesophageal prosthesis, in terms of prosody, speech intelligibility in sentences and spontaneous conversation, and pitch changes in singing.

\section{Method}

\section{Subjects}

Seventeen totally laryngectomized patients fitted In-Health prostheses took part in this study The group was comprised of 16 male and one female patient. The female patient was kept in this study once the proportion reflected in this study is the same found in the literature, which shows a greater number of men with larynx cancer. The world statistics show the proportion of 10 men to 1 woman (Noronha \& Dias, 1997).

The age of the group varied from 40 to 81 years old, with academic level ranging from illiterate to third high school degree, with the majority of patients with incomplete primary school.

\section{Procedure}

The study comprised four steps, as follows:

1. Interview and pre-training speech sample collection.

In the first step, the patient was interviewed using a previously established script, according 
to a protocol found in Appendix A. Also, the patients were advised of the nature of recommended speech training and were asked to voluntarily participate in the study. Patients' recorded speech and voice samples were obtained.

For the collection of voice and speech samples, the patients were recorded in an acoustically treated room. A Sanyo tape recorder was used with an internal microphone and a BASF CE II 60-minute tape. The tape recorder was placed near the subject's mouth, at a distance of $30 \mathrm{~cm}$.

The script for audio recording (Appendix B) basically included the following procedures:

- sustained emission of the vowels [a, i, u];

- reading or speaking three melodically distinct sentences (affirmative and interrogative). Illiterate or low level of literacy patients, repeated the stimuli after the clinician who read both the affirmative and interrogative sentences;

- singing the song "Happy birthday to you";

- answering generic assertive questions, in order to provide a sample of the spontaneous speech. Example: What do you like to do at home? What do you like to eat?

\section{Speech training.}

Step two involved speech training and consisted of four sessions of thirty minutes. Whenever necessary, a fifth session was scheduled with the patient in order to conclude the entire program.

The speech training was conduced by two speech and hearing pathologists, previously instructed, who followed the same procedure. The program used in the sessions is described in Appendix C. Generally, the program comprised the following topics:

- breathing coordination, specially exhaling with a digital occlusion of the prosthesis;

- articulatory production training in order to reflect a better process of voice production;

- articulatory training associated with exercises for the improvement of speech prosody in sentences, singing and relaxed speech;

- internalization of the practiced aspects;

\section{Post-training speech sample collection.}

Step 3 involved re-recording of the patient. The evaluation protocol was the same one used previously, following the identical inventory and audio recording procedure, in order to compare the pre and post-training samples.

\section{Auditory perceptive analysis of voice and} speech.

Sample's organisation and judgements' analysis procedures.

For each subject two voice and speech samples were collected, pre and post-training. Thus, a total of 34 samples were obtained. Such samples were numerically identified, were randomly arranged and tape recorded to form a master listening tape.

The auditory-perceptive analysis of the samples were performed by three judges (speech and hearing pathologist, specialized in voice). Judges were not informed before the analysis as to whether or not a patient's sample represented pre or post-training; and each listener received a tape with all 34 speech and voice samples together with 34 numerically organized protocols according to the number played in the recording, to be filled out. (Appendix D).

The judges responded to each item on the listening protocol with "Good, Acceptable or Bad" and were converted to numeric values $(3,2,1$ respectively) and summed to derive a final score for each patient.

\section{Analysis criteria}

Next, the items considered for the samples' evaluation are described.

Sentence melody - the following definitions were established for judging the subjects' affirmative and negative utterances: Good - when a consistent distinction between the affirmation and interrogation was considered; Acceptable - when an inconsistent distinction between the affirmation and interrogation was considered; and $\mathrm{Bad}-$ when it wasn't possible to discern any distinction between the affirmation and interrogation melodic curves.

Sentence production intelligibility - the definitions were: Good - when the subject presented enough speech intelligibility; Acceptable - when the speech was considered reasonably intelligible; and $\mathrm{Bad}-$ when it was very distorted.

Spontaneous speech intelligibility - for this item the definitions were: Good - when there was 
preponderant speech intelligibility; Acceptable when there was an understanding of part of the utterances, not hindering the communication sense; and Bad - when the majority of the utterances were distorted.

Singing voice melody - the definitions were: Good - when it was judged that the subject sang with a similar melody and rhythm to a common person's singing; Acceptable - when the subject sang with certain melody and rhythm variations but close to a common person's singing; and Bad - when it was not possible to realize melody and rhythm variations.

Pitch - the choices were low, medium, high, and a forth option of not possible to define, whenever it was judged this way.

Vocal quality - the possibilities of vocal quality presented were hoarse, murmured and harsh, and the possible degrees were mild, moderate and severe. Listeners were also asked to use some other designation of vocal quality whenever it was necessary.

For each item there was a final score which represented the sum of each listener's judgments for each subject.

\section{Results}

The mean age of the subjects was 56,0 years, with a predominant age of 40 to 50 years $(41,2 \%)$. Only two patients were between 51 and 60 years old, and the other ones (seven) were over 61 years of age. The majority of the patients $(64,7 \%)$ achieved incomplete primary school, two subjects were illiterate and one had university degree .

Regarding the smoking habit, considered by the literature as a factor associated to laryngeal cancer, only one subject was a non-smoker. The smoking group (16 subjects) presented an average of smoking habit of 34,8 years, and $73,3 \%$ referred having smoked for more than 30 years.

One female subject had a no - alcohol history. The remaining subjects reported many years of drinking that averaged to 30.2 years.

Three subjects had the primary prosthesis placement, that is, implanted during the total laryngectomy. The majority of the subjects experienced secondary prosthesis placement through high digestive endoscopy.
The average time interval between the total laringectomy and the tracheoesophageal prosthesis placement for the 14 patients $(82,0 \%)$ was 17,5 months.

Regarding the results of the pre-speech training and post-speech training, it was observed that 11 subjects $(64,7 \%)$ presented improvements, two subjects didn't have alterations in their evaluations and four presented worse scores in the posttraining period (see Appendix E).

For a better understanding of the results of the speech training, we present the annex 5 which correlates the subjects' results of the pre and posttraining evaluations; the last column shows the final improving or declining situations, or those in which the result was not altered.

Table1 presents the group's post-speech training results where it can be seen a significant statistical difference between the number of improvements in relation to the number of declines. The whole set of the evaluated items was considered here: sentence melody, sentence intelligibility, spontaneous speech intelligibility and singing voice melody. Some subjects had the maximum score (concept "good") in some items in the pre-training evaluation, reducing the number of items that could possibly improve Therefore, it was observed that 18 items presented a better posttraining evaluation.

Table 2 shows the improvements of the posttest scores in the four aspects. For each evaluated aspect, it can be seen in the third column the number of patients with evaluation improvement. A greater number of subjects presented improvement in the items sentence melody and singing.

It is important to stress that slight variation was found in the aspects of sentence and spontaneous speech intelligibility, however, a higher number of maximum scores (score 3) already in the pre-test was found in these aspects. In the sentence production intelligibility there were eight subjects with score 3, and in the spontaneous speech intelligibility, five subjects obtained the maximum score. Concerning the sentence melody and singing, 12 subjects improved in the post-test evaluation. We stress that only one subject obtained maximum score for singing in the pre-test, that is, in the judge's opinion the subject presented melody and rhythm similar to a non-lalryngectomee's singing.

The same happened with the spoken sentence melody where only two subjects obtained the maximum score already in the pre-test. The singing score improvement and the number of subjects with evaluation improvement in this aspect can be underlined. 
TABLE 1. Voice and Speech improvements in the set of four evaluated items.

\begin{tabular}{cccc} 
& Número & $\mathrm{P}$ & Resultado \\
itens com melhora & 18 & $0,0123^{*}$ & significante \\
itens com piora & 5 & & \\
\hline
\end{tabular}

*valor de p menor que 0,05 (Teste da Binomial).

TABLE 2. Pre and Post - test scores obtained in the four evaluated items and the Number of subjects with improvement.

\begin{tabular}{cccc} 
& $\begin{array}{c}\text { Nota do Grupo no } \\
\text { Pré-Teste }\end{array}$ & $\begin{array}{c}\text { Nota do Grupo } \\
\text { no Pós-Teste }\end{array}$ & $\begin{array}{c}\text { Número de } \\
\text { Sujeitos } \\
\text { com Melhora }\end{array}$ \\
\hline melodia frasal & 29 & 33 & 5 \\
$\begin{array}{c}\text { inteligibilidade em } \\
\text { emissão de frases }\end{array}$ & 40 & 42 & 3 \\
$\begin{array}{c}\text { inteligibilidade em } \\
\text { fala espontânea }\end{array}$ & 39 & 41 & 3 \\
canto & 32 & 36 & 7 \\
\hline
\end{tabular}

TABLE 3. Sentence Melody improvements control.

\begin{tabular}{cccc} 
& Número & $\mathrm{P}$ & Resultado \\
\hline melhora & 5 & 0,109 & não significante \\
piora & 1 & & \\
\hline
\end{tabular}

$\mathrm{P}<0,05$ (teste da Binomial).

TABLE 4. Sentences production and Spontaneous speech Intelligibility improvements control.

\begin{tabular}{lccc} 
& Número & $\mathrm{P}$ & Resultado \\
$\begin{array}{l}\text { inteligibilidade em frases } \\
\text { melhora }\end{array}$ & 3 & 1,000 & não significante \\
$\quad$ piora & 1 & & \\
$\quad \begin{array}{l}\text { melhora } \\
\text { piora }\end{array}$ & 3 & 1,000 & não significante \\
\hline
\end{tabular}

$\mathrm{P}<0,05$ (teste da Binomial).

TABLE 5. Singing melody Improvement control.

\begin{tabular}{ccc|c} 
& Número & $\mathrm{P}$ & Resultado \\
melhora & 7 & 0,090 & não significante \\
piora & 2 & & \\
\hline
\end{tabular}

$\mathrm{P}<0,05$ (teste da Binomial).

P<
Concerning the sentence melody, table 3 reveals that the number of improvements in the post-test was not statistically significant. Considering that two subjects already had the maximum score in this item, it can be stressed that $33,3 \%$ of the patients improved in the post-training evaluation. Five presented concept "bad" for this aspect that was not altered in the post-test.

Table 4 presents the statistical analysis of the changes between pre-training and post-training in the sentence production and spontaneous speech intelligibility. The number of improvements for this item seems low, however it is relevant to stress that nine subjects $(52,9 \%)$ presented the concept "good" (score 3) already in the initial evaluation for the sentence production intelligibility. Out of the other eight patients, four obtained minimum score, and among them, two showed improvement in the post-test and the other two maintained the same score. The only case with a decrease in the concept had initially a maximum evaluation and in the post-test, his articulation was considered acceptable. It is possible to say that $37,5 \%$ of the group presented improvement in the post-test, although not statistically significant.

A similar number of subjects (eight) also presented maximum concept in the pre-test for the spontaneous speech intelligibility, and therefore no statistical difference was found (table 4). Of the 9 patients with a possibility to show improvement in the post-test evaluations, three $(33,3 \%)$ did so. The same subject who presented a decline in the item mentioned above, also presented in this item.

Regarding the singing melody evaluation, it can be verified in table 5 that seven subjects $(43,7 \%)$ were able to show improvement in the posttraining. Only one subject had an evaluation with the concept "good" in the pre-training.

Concerning the pitch, all subjects were classified by the judges as severe either in the pretest as in the post-test, and the voice quality was considered hoarse in $100 \%$ of the cases, with an indication of hoarse-harsh for seven $(41,1 \%)$. The variation in these aspects classification didn't show relevant alterations in both moments. 


\section{Discussion}

Regarding the results of the speech training, when we compared the group's scores in the pre and post-training situations, we could observe that 11 of the 17 patients presented improvement in at least one of the four evaluated items, two patients didn't have any alteration in their evaluation and four subjects presented worse scores in the post training period. It was detect that those four subjects had prosthesis placement complications, such as displacement of it, presence of granulomas, or even general health problems.

We could verify that the incidence of improvements was significant in relation to the declines only for all parameters. The cases that could not present improvement in the posttraining, once they were already "good" in the pretraining, influenced the analysis not allowing to evaluate the effectiveness of the treatment, when considering each isolated aspect. This occurred mainly in the items sentence production and spontaneous speech intelligibility, where there was a tendency to consider the patients "acceptable" or "good" already in the pre-training evaluation,

\section{Conclusion}

In general, we can state that the speech training proposed in order to improve the oral communication of laryngectomee patients who chose to use the tracheoesophageal prosthesis revealed positive results.

Even considering that the proposed training was of short term (four sessions), we can conclude that it is important to counsel the tracheoesophageal prosthesis user to take the maximum advantage possible of this resource, since we found a relevant number of improvements in what could justify the little score variation between the pre and post-training. Such factor did not happen in the sentence melody and singing items.

The sentence melody and singing were the aspects with higher incidence of concepts improvement, suggesting that the speechlanguage therapy for laryngectomized patients with tracheoesophageal prosthesis, emphasizing the melodic variation can improve their communication quality that is considered, according to the literature, as having a monotone tendency voice. It can be said that this is the greatest criticism pointed by the literature. Thus, the melodic exercises used during the training seem to have positively influenced the results and we believe that the training helped the subjects to better use the sound source obtained through the tracheoesophageal prosthesis.

Although the singing voice performance is very dependent on spontaneity or discomfiture of the person who is singing, we can consider relevant the number of evaluations pointing improvements. the post-training evaluation. The Binomial test showed a significant statistical result when the set of the four evaluated items (sentence melody, sentence production and spontaneous speech intelligibility, and singing voice melody) was considered for the analysis.

We can conclude that speech-language treatment is important for patients with tracheoesophageal prosthesis in order to provide a better use of it, with a consequent communication improvement and, therefore, life quality improvement. 


\section{References}

BEHLAU, M. S.; PONTES, P. A. L.; ZIEMER, R.; Reabilitação vocal do paciente laringectomizado. In: FERREIRA, L. P. Trabalhando a voz: vários enfoques em Fonoaudiologia. 3. ed. São Paulo: Summus Editorial, 1988.

BLOM, E. D.; SINGER, M. I.; HAMAKER, R. C. A prospective study of tracheoesophageal speech. Arch Otolaryngol Head Neck Surgery, v. 112, n. 4, p. 440-447, apr. 1986.

CHOY, H. S.; PARK, Y. J.; LEE; KIM, K. M. Functional characteristics of a new eletrolarynx "Evada" having a force sensing resistor sensor. Journal of Voice, v. 15, n. 4, p. 592-599, 2001.

COSTA, C. C.; RAPOPORT, A.; CHAGAS, J. F. S.; OLIVEIRA, I. B.; CASTRO, P.; MAGNA, L. A. Reabilitação vocal de laringectomizados com prótese traqueoesofágica. Revista Brasileira de Otorrinolaringologia, v. 65 n. 5, p. 707-714, 2001.

FINIZIA, C.; HAMMERLID, E.; WESTIN, T.; LINDSTROM, J. Quality of life and voice in patients with laryngeal carcinoma: a post-treatment comparison of laryngectomy (Salvage Surgery) versus radiotherapy. The Laryngoscope, v. 10, n. 8, p. 1566-1573, 1998.

GRECO, A. M.; NEMR, K.; KÖHLE, J. I.; RIBEIRO, S. G.; CURIONI, O. A. Voz esofágica após faringolaringectomia e paralisia do hipoglosso - relato de caso. Pró-Fono Revista de Atualização Científica, Barueri, v. 15, n. 1, p. 41-44, jan.-abr. 2003.
JORGE, M. S.; GREGIO, F. N.; CAMARGO, Z. Qualidade vocal ed indivíduos submetidos a laringectomia total: aspectos acústicos de curto e de longo termo em modalidades de fonação esofágica e traqueoesofágica. Rev. CEFAC Atualização Científica em Fonoaudiologia, São Paulo, v. 6, n. 3, p. 319-328, jul.-set., 2004.

LABRUNA, A.; HUO, J. Tracheoesophageal puncture in irradiated patients. Ann. Otol. Rhinol. Laringol., v. 104, n. 2, p. 279-281, 1995.

NASCIMENTO, L. A.; Análises perceptiva - auditiva, temporal e acústica computadorizada da voz em pacientes submetidos à laringectomia parcial supracrióidea com cricohiodopexia ou criohiodoepiglotopexia. 1999. $87 \mathrm{f}$. Dissertação (Mestrado em Otorrinolaringologia e Cirurgia de Cabeça e Pescoço) - Universidade Federal de São Paulo Escola Paulista de Medicina, São Paulo.

NORONHA, M. J. R.; DIAS, F. L. Epidemiologia - etiologia e fatores etiológicos do câncer de laringe - potencial para a quimioprevenção. In: NORONHA, M. J. R.; DIAS, F. L. Câncer da laringe: uma abordagem multidisciplinar. Rio de Janeiro: Revinter, 1997. cap. 2, p. 4-7.

VAN AS, C. J.; HILGERS, F. J. M.; DE LEEUW, I. M. V. BEINUM, F. J. K. Acoustical Analysis and Perceptual Evaluation of Tracheoesophageal Prosthetic Voice; Journal of Voice, v. 12, n. 2, p. 239-248, 1998.

\section{Bibliografia Consultada}

SIEGEL, S. Estatística não paramétrica - para as ciências do comportamento. São Paulo: McGraw-Hill, 1975. 350 p. 


\section{Apêndice A}

Roteiro para entrevista inicial

Data: $\quad$ Fonoaudióloga responsável:

\section{Identificação}

Nome do paciente:

Sexo: $\mathrm{M}(\mathrm{)} \quad \mathrm{F}(\mathrm{)}$

Data de nascimento:

Endereço:

Telefone:

Nível de instrução:

Profissão:

Nome do cônjuge:

Data da cirurgia:

Data da colocação da prótese:

2. Hábitos (atuais/anteriores à cirurgia):

Tabagismo: Sim ( ) Não ( ) Há quanto tempo?

Etilismo: Sim ( ) Não ( ) Há quanto tempo?

Parou de fumar? Sim ( ) Não ( ) Há quanto tempo?

Parou de ingerir bebidas alcoólicas? Sim ( ) Não ( )

Há quanto tempo:

\section{Recuperação pós-cirúrgica:}

Complicações pós-operatórias? Sim ( ) Não ( )

Quais?

Quando passou a alimentar-se por via oral?

Apresenta disfagia? Sim ( ) Não ( )

Há quanto tempo?

4. Queixas atuais:

Dificuldades de alimentação? Sim ( ) Não ( )

Odinofagia? Sim ( ) Não ( )

Cialorréia? Sim ( ) Não ( )

Dificuldades para dormir? Sim ( ) Não ( )

Dificuldade na higienização da prótese? Sim ( ) Não ( )

Observação:

5. Relacionamento sócio - familiar:

Apresenta dificuldade de relacionamento com a família?

Sim ( ) Não ( )

Quais?

Apresenta dificuldade de comunicação? Sim ( ) Não ( )

Quais?

\section{Apêndice B}

Protocolo para avaliação (Pré e Pós-Treino Fonoaudiológico)

1. Manuseio da prótese vocal: ( ) Bom ( ) Regular

( ) Insuficiente

2. Coordenação pneumofônica digital (respiração coordenada ao ato de ocluir digitalmente a prótese e iniciar a fonoarticulação):

( ) Boa ( ) Regular ( ) Insuficiente

3. Emissão de vogal sustentada (segundos):

/a/: , /i/: , /u/:
4. Frases para leitura, afirmativas e interrogativas (para avaliação da prosódia):

. Posso comer pipoca?

. Posso comer pipoca;

. José pintou a porta de branco?

. José pintou a porta de branco;

. Fernando viajou para Natal?

. Fernando viajou para Natal.

5. Melodia:

Cantar "Parabéns a Você" 


\section{Apêndice C}

Roteiro proposto para o treinamento fonoaudiológico (Tópicos desenvolvidos nas quatro sessões semanais de 30 minutos)

Primeira sessão de treinamento - treino de manuseio da prótese:

. Orientação quanto à coordenação pneumofônica e digital da prótese, durante a fala. Exercícios de controle respiratório, com ênfase em região costodiafragmática.

Segunda sessão de treinamento - treino articulatório e da qualidade vocal:

. Treino da fala com sons plosivos iniciais $(/ \mathrm{p} / ; / \mathrm{t} / ; / \mathrm{k} / ; / \mathrm{b} /$ ; /d/;/g/);

. Treino com a técnica de mascado vocal (fröeschls); . Orientação para postura facilitadora da melhor articulação e produção vocal.
Terceira sessão de treinamento - treino articulatório e da prosódia em fala distensa:

Treino da fala envolvendo demais fonemas do português . Treino da prosódia: curvas de afirmação e interrogação; . Treino da melodia na voz cantada.

Quarta sessão de treinamento:

. Treino articulatório e revisão do conteúdo das sessões anteriores;

. Coleta da voz do paciente seguindo a mesma metodologia da fase inicial.

Observação: quando necessária foi realizada uma sessão adicional para os pacientes que apresentaram dificuldade em manusear a prótese e coordenar a produção sonora desta.

\section{Apêndice D}

Análise perceptivo-auditiva de amostras de voz e fala (Roteiro utilizado pelos juízes para a análise)

Amostra número:

1. Análise da melodia frasal (prosódia)

Comparando-se a prosódia ou curva melódica entre as duas frases ouvidas, esta prosódia, em sua opinião, é:

Boa ( ) - demonstra distinção consistente (perceptível) entre a afirmação e a interrogação.

Regular ( ) - demonstra distinção inconsistente (não claramente perceptível) entre a afirmação e a interrogação

Ruim ( ) - não é possível perceber distinção entre as curvas melódicas de afirmação e interrogação.

2. Análise da produção articulatória das amostras Considerar para análise as frases e a fala espontânea.

Quanto às frases, a inteligibilidade é:

Boa ( ) - apresenta inteligibilidade de fala suficiente nas produção das frases.

Regular ( ) - apresenta inteligibilidade razoável na emissão das frases.

Ruim ( ) - inteligibilidade bastante comprometida.

Quanto à fala espontânea em geral, a inteligibilidade é:

Boa ( ) - inteligibilidade de fala suficiente na maioria das vezes.

Regular ( ) - inteligibilidade de fala em parte das emissões não comprometendo o sentido geral da comunicação.
Ruim ( ) - inteligibilidade de fala comprometida na grande maioria das emissões comprometendo a comunicação.

3. A melodia e o ritmo da voz cantada desta amostra é:

Boa ( ) - o sujeito canta com melodia e ritmo próximos da normalidade do canto de pessoas comuns.

Regular ( ) - o sujeito canta com certas variações de melodia e ritmo com proximidade ao canto de pessoas comuns.

Ruim ( ) - não é possível perceber variações de melodia e ritmo no canto do sujeito.

\section{Análise do pitch}

O pitch desta amostra de voz mostra-se:

Grave ( ) Médio ( )

Agudo ( ) Não há possibilidade de definição ( )

Outros ( ) Especifique:

5. Análise da qualidade vocal da amostra:

Esta voz mostra-se:

\begin{tabular}{lccc}
\multicolumn{2}{r}{ Levemente } & Moderadamente & Severamente \\
Soprosa - & ( ) & ( ) & ( ) \\
Rouca - & ( ) & ( ) & $($ ) \\
Áspera - & ( ) & ( ) & ( )
\end{tabular}

Favor especificar outras qualidades, conforme julgar necessário (será de grande ajuda):

Observações: (reservamos este espaço para quaisquer comentários com relação à amostra ouvida) 


\section{Apêndice E}

Relação de notas pré e pós-treino fonoaudiológico

\begin{tabular}{|c|c|c|c|}
\hline Sujeitos & $\begin{array}{l}\text { Notas Obtidas no } \\
\text { Pré-Treino }\end{array}$ & $\begin{array}{l}\text { Notas Obtidas no } \\
\text { Pós-Treino }\end{array}$ & Situação Final \\
\hline 1 & 7 & 10 & melhora \\
\hline 2 & 11 & 12 & melhora \\
\hline 3 & 7 & 8 & melhora \\
\hline 4 & 10 & 11 & melhora \\
\hline 5 & 11 & 11 & inalterada \\
\hline 6 & 8 & 11 & melhora \\
\hline 7 & 7 & 6 & piora \\
\hline 8 & 4 & 5 & melhora \\
\hline 9 & 12 & 10 & piora \\
\hline 10 & 4 & 7 & melhora \\
\hline 11 & 9 & 10 & melhora \\
\hline 12 & 9 & 12 & melhora \\
\hline 13 & 10 & 12 & melhora \\
\hline 14 & 8 & 5 & piora \\
\hline 15 & 11 & 10 & piora \\
\hline 16 & 4 & 4 & inalterada \\
\hline 17 & 4 & 5 & melhora \\
\hline
\end{tabular}

Lembramos que as notas para cada item avaliado variaram de "um" quando o conceito foi considerado ruim a "três" para o conceito bom. Desta forma, a nota mínima obtida na avaliação foi quatro (por serem quatro aspectos analisados) e doze, no caso de o sujeito conseguir conceito máximo nos quatro itens avaliados.

Endereço para correspondência:

Iára Bittante de Oliveira

R. Sacramento, 126, conj. 63/64 - Centro - Campinas - SP - CEP: 13010-911. 